\title{
Budaya Tradisi sebagai Identitas dan Basis Pengembangan Keramik Sitiwinangun di Kabupaten Cirebon
}

\author{
Deni Yana, Reiza D. Dienaputra, Agus S. Suryadimulya, Yan Yan Sunarya \\ Program Doktor Kajian Budaya Program Studi Ilmu Sastra Fakultas Ilmu Budaya \\ Universitas Padjadjaran \\ Jl. Raya Bandung Sumedang No. KM 21, Hegarmanah, Jatinangor, Kabupaten Sumedang, \\ Jawa Barat 45363 \\ Tlp. 0818206704, E-mail: deniyana75@yahoo.co.id
}

\begin{abstract}
This research is motivated by the condition of the Sitiwinangun ceramics center in Jamblang Sub-district, Cirebon Regency, whose products are currently declining both in quality and quantity. This situation is ironic considering that the center has quite strong natural, human and cultural resources. The purpose of this research is to develop Sitiwinangun ceramic handicraft products through the use of local traditions culture as a reinforcement of its identity and product development base. This study uses a cultural and aesthetic approach through aesthetic morphological theory and the ATUMICS method with stages of identification, analysis, design development, design application and evaluation. The results of this study in the form of more modern ceramic products in the form of works of art, decoration and function with the cultural identity of the local tradition of Cirebon. Traditional culture in the context of conservation and revitalization of ceramic crafts in general can be an alternative basis for the development and strengthening of the local identity of its products.
\end{abstract}

Keywords: Sitiwinangun, ceramics, identity, tradition, culture

\begin{abstract}
ABSTRAK
Penelitian ini dilatarbelakangi oleh kondisi sentra kerajinan keramik Sitiwinangun di Kecamatan Jamblang Kabupaten Cirebon yang produknya saat ini semakin menurun baik secara kualitas maupun kuantitas. Keadaan ini merupakan hal yang ironis mengingat sentra tersebut memiliki potensi sumber daya alam, manusia, dan budaya yang cukup kuat. Tujuan penelitian ini adalah untuk mengembangkan produk kerajinan keramik Sitiwinangun melalui pemanfaatan budaya tradisi lokal sebagai penguatan identitas dan basis pengembangan produknya. Penelitian ini menggunakan pendekatan budaya dan estetika melalui teori morfologi estetik dan metode ATUMICS dengan tahapan identifikasi, analisis, pengembangan desain, aplikasi desain, dan evaluasi. Hasil dari penelitian ini berupa produk keramik yang lebih modern dalam bentuk karya seni, hias, dan fungsi dengan identitas budaya tradisi lokal Cirebon. Budaya tradisi dalam konteks konservasi dan revitalisasi kerajinan keramik secara umum dapat menjadi alternatif sebagai basis pengembangan dan penguatan identitas lokal produknya.
\end{abstract}

Kata Kunci: Sitiwinangun, keramik, identitas, tradisi, budaya

\section{PENDAHULUAN}

Perkembangan keramik di Indonesia secara umum dari masa prasejarah hingga saat ini berdasarkan sejarahnya yang cukup panjang dapat dilihat dari segi teknis dan konsep. Hadirnya produk keramik yang lebih modern di Indonesia dilatarbelakangi oleh pendirian Laboratorium Keramik di Bandung pada tahun 1922 yang memperkenalkan teknologi keramik bakaran 
suhu tinggi. Laboratorium Keramik yang kemudian berubah namanya menjadi Balai Besar Keramik (BBK) ini telah mendorong munculnya industri-industri keramik di beberapa daerah di Indonesia khususnya di wilayah perkotaan dengan kapasitas produksi yang cukup besar. Produk keramik yang dihasilkannya sangat beragam dari mulai alat untuk kebutuhan sehari-hari seperti tableware sampai dengan komponen bangunan seperti ubin, roster, genteng, dan lain-lain dengan teknologi yang cukup tinggi. Sedangkan perkembangan keramik secara konseptual diinisiasi oleh beberapa perguruan tinggi seni di Indonesia yang membuka studio keramik seperti Departemen Seni Murni Institut Teknologi Bandung (ITB) pada tahun 1963, Akademi Seni Rupa Indonesia (ASRI) di Yogyakarta pada tahun 1970, dan Institut Kesenian Jakarta (IKJ) pada tahun 1977. Beberapa lulusan dari perguruan-perguruan tinggi seni tersebut kemudian muncul menjadi seniman dan kriyawan keramik dengan hasil karyanya yang eksperintal, kreatif, dan inovatif. Kecenderungan ini terlihat ketika keramik dipergunakan sebagai salah satu media ekspresi personal dalam lingkup seni rupa modern Indonesia. Beberapa nama yang muncul sebagai contoh antara lain: Alm. Hildawati Soemantri, Alm. Hendrawan Riyanto, F. Widayanto, Alm. Suyatna, dan lainlain. Perkembangan keramik secara konseptual ini sangat dipengaruhi oleh pendidikan seni rupa barat, sehingga dapat dikatakan bukan merupakan kelanjutan dari tradisi pembuatan keramik pada masa sebelumnya di Indonesia. (Riyanto, 2000, hlm. 54).
Perkembangan baru dalam dunia keramik di Indonesia dari segi teknik dan konsep ternyata tidak menyebabkan hilangnya tradisi pembuatan keramik tradisional yang telah berkembang di masyarakat sebelumnya, hal ini terbukti dengan tetap bertahannya tradisi pembuatan kerajinan keramik tradisional yang tersebar di beberapa daerah di Nusantara salah satunya yaitu sentra kerajinan keramik Sitiwinangun di Kecamatan Jamblang Kabupaten Cirebon (Yana, 2014, hlm. 358).

Kabupaten Cirebon merupakan bagian dari wilayah Provinsi Jawa Barat yang memiliki luas wilayah 990,4 km persegi dan terdiri dari 40 Kecamatan (Dirjen IKM, 2014, hlm. 53). Desa Sitiwinangun merupakan sentra kerajinan keramik terbesar di Kabupaten Cirebon yang terletak di Kecamatan Jamblang, sekitar $15 \mathrm{~km}$ ke arah barat Kotamadya Cirebon. Luas wilayah desanya hanya sekitar 65.432 hektar. Desa ini terbagi menjadi 5 blok yaitu: Kebagusan, Caplek Kidul, Caplek Lor, Lebak, dan Sentul dengan jumlah penduduk saat ini sekitar 5.121 jiwa (Profil Desa sitiwinangun, 2016, hlm. 4).

Tradisi pembuatan kerajinan keramik di Desa Sitiwinangun telah memiliki sejarah yang cukup panjang sejak masa prasejarah hingga saat ini. Nama Sitiwinangun memiliki arti: tanah yang dibangun atau dibentuk (Siti $=$ tanah, Winangun = bentuk). Kepandaian membuat kerajinan keramik masyarakat Desa Sitiwinangun diperoleh dari pendiri Desa Sitiwinangun yang bernama Ki Bagus Pranata atau sering disebut sebagai Buyut Kebagusan yang sambil menyebarkan agama 
Islam juga mengajarkan keahlian membuat kerajinan keramik untuk mata pencaharian masyarakatnya. Ada sebuah ritual tradisi yang berkaitan dengan kepandaian membuat keramik, yakni apabila seseorang ingin memiliki kepandaian membuat keramik, maka ia harus berjalan mengelilingi pagar makam seorang punggawa Ki Bagus Pranata yang bernama Ki Jaya Baya dengan menahan nafas sebanyak 3 keliling, sambil menyangga batu yang tersebar di sekitar makam. Apabila ia mampu membawa batu ukuran besar sambil berkeliling, maka ia akan memiliki kepandaian membuat barang-barang yang berukuran besar seperti: gentong, gosang, paso, dan lain-lain. Namun, apabila ia hanya mampu membawa batu ukuran kecil, maka ia hanya akan memiliki kepandaian membuat keramik ukuran kecil seperi pendil, kendi, cobek, dan lain-lain. Sebagai penghormatan masyarakat Desa Sitiwinangun kepada Buyut Kebagusan, lokasi pemakam tokoh tersebut kini dijadikan situs Mesjid Keramat Kebagusan yang di dalamnya terdapat benda kuno sebagai pusaka berupa masjid kuno, Al-Qur'an, dan benda keramik yang sudah berusia ratusan tahun. (Dinartisti, 2013, hlm. 137).

Berdasarkan data kependudukan Desa Sitiwinangun tahun 2016, perajin keramik di Sitiwinangun hanya tinggal sekitar 73 orang yang sebagian besar adalah para manula dan mereka tersebar di dua lokasi yaitu Kebagusan dan Caplek Kidul. Kondisi ini merupakan hal yang sangat memprihatinkan mengingat kerajinan keramik Sitiwinangun merupakan salah satu aset budaya dan ekonomi daerah Kabupaten Cirebon yang jika dikembangkan akan menarik banyak tenaga kerja dan dapat meningkatkan taraf ekonomi masyarakatnya. Sampai saat ini perajin yang masih bertahan kebanyakan para perempuan berusia lanjut sebab para perajin laki-lakinya sudah banyak yang meninggal. Sementara para generasi muda di daerah tersebut banyak yang kurang berminat untuk mengikuti jejak para orang tuanya dengan bekerja di luar kota.

Menyikapi permasalahan tersebut, dalam upaya konservasi untuk menghindari sentra dari kepunahan, pemerintah Desa Sitiwinangun pada bulan Februari tahun 2016 telah mencanangkan sentra kerajinan keramik Sitiwinangun sebagai desa wisata dan diresmikan oleh Sultan Cirebon pada akhir tahun 2018. Pengembangan desa wisata adalah suatu bentuk implementasi dari program pemberdayaan masyarakat yang salah satu tujuannya adalah memecahkan masalah yang berkaitan dengan krisis ekonomi dan meningkatkan kesejahteraan masyarakat desa (Chamidah, 2019, hlm. 7). Sejak diresmikan sebagai desa wisata, jumlah kunjungan konsumen dan wisatawan yang berkunjung langsung ke sentra kerajinan keramik Sitiwinangun meningkat cukup signifikan. Sayangnya peluang tersebut belum dapat dimanfaatkan secara optimal oleh perajin keramik Sitiwinangun karena produk yang dibuat oleh perajin keramik Sitiwinangun masih cenderung monoton dan kurang inovatif. Sementara wisatawan dan konsumen yang datang ke sentra sangat membutuhkan produk kerajinan keramik yang estetis, praktis, dan ekonomis namun tetap memiliki identitas budaya lokal sebagai 
ciri khasnya.

Berdasarkan latar belakang tersebut, penelitian ini bertujuan untuk meningkatkan kreatifitas dan kesejahteraan perajin keramik Sitiwinangun melalui pengembangan produk kerajinan keramik Sitiwinangun agar sesuai dengan kebutuhan konsumen melalui pemanfaatan budaya tradisi lokal dalam aspek bentuk dan motif yang merupakan kekhasan keramik Sitiwinangun Kabupaten Cirebon sebagai landasan untuk pengembangan dan penguatan identitas lokal produknya.

\section{METODE}

Penelitian ini merupakan penelitian kualitatif dengan pendekatan budaya dan estetika untuk mengungkapkan hubungan antara nilai-nilai budaya tradisi dengan masyarakat modern dalam kehidupan sekarang, khususnya terhadap produk kerajinan keramik Sitiwinangun. Selain itu juga untuk mendapatkan gambaran mengenai bagaimana perajin keramik memanfaatkan unsur-unsur budaya tradisi dalam proses membuat produk kerajinan keramiknya. Metode yang digunakan dalam penelitian ini adalah morfologi estetis dan metode ATUMICS. Metode morfologi estetis (Munro, 1970, hlm. 6) merupakan metode untuk memahami bentuk dan gaya serta perubahan teknik antar bagian dalam karya seni. Kajian tentang bentuk dimulai dari mengamati keseluruhan komposisi penyusun dari obyek itu sendiri yaitu pertama: elemen, detil, bagian, material, image, ide atau unsur pembentuk lainnya. Kedua: cara masing-masing unsur dihubungkan dan dikombinasikan sehingga membentuk struktur produk. Kemudian dalam upaya membentukstruktur produk baru akan digunakan metode ATUMICS (Nugraha, 2012, hlm. 175) suatu metode yang digunakan dalam upaya melakukan transformasi artefak tradisional menjadi artefak modern melalui penyusunan, kombinasi, integrasi, atau penggabungan antara elemen objek yakni: Artefack, Technique, Utility, Material, Icon, Concept, Shape. Adapun tahapan pelaksanaan kegiatannya adalah sebagai berikut: identifikasi, analisis, pengembangan desain, aplikasi desain, dan evaluasi.

Tahapan identifikasi dilakukan dengan dua cara, yaitu secara langsung dan tidak langsung. Pengamatan secara langsung dilakukan melalui tinjauan langsung ke sentra (observation). Melalui observasi dapat dilakukan wawancara dengan perajin dan pengamatan secara langsung terhadap obyek yang diteliti sebagai data awal selain dilakukan juga kunjungan ke beberapa tempat yang mengoleksi produk keramik Sitiwinangun. Adapun proses identifikasi secara tidak langsung dilakukan dengan mengumpulkan data literatur/dokumentasi dalam bentuk katalog pameran keramik Sitiwinangun. Selain dari katalog data primer lainnya diperoleh melalui buku-buku yang berhubungan dengan kebudayaan, sejarah, dan keramik antara lain buku Pengantar Wawasan Seni Budaya, The Craft Of Indonesia, Perjalanan Seni Rupa Indonesia dari Zaman Prasejarah Hingga Masa Kini, Filsafat Seni, katalog pameran 3000 Tahun Terakota Indonesia, serta hasil-hasil penelitian yang relevan. Data yang diperoleh selanjutnya 
dianalisis secara deskriptif berdasarkan unsur-unsur budaya tradisi yang digunakan pada kerajinan keramik Sitiwinangun. Hasil analisis data kemudian dijadikan dasar untuk tahapan berikutnya yaitu pengembangan sketsa/desain produk. Pengembangan sketsa/desain ini dilakukan melalui proses eksplorasi ide/gagasan berdasarkan hasil analisis data yang kemudian diaplikasikan dalam pembuatan model (mock up). Setelah selesai proses pembuatan model (mock up) selanjutnya dilakukan evaluasi secara terpadu terhadap hasil pengembangan produk baru.

\section{HASIL DAN PEMBAHASAN}

Budaya dalam pengertian umum biasa diartikan sebagai akal atau budi. Para pakar antropologi budaya Indonesia umumnya sependapat bahwa kata kebudayaan berasal dari bahasa Sansekerta buddhayah yang merupakan bentuk jamak dari buddhi yang berarti budi atau akal (Maran, 2000, hlm. 24). Dapat juga ditafsirkan bahwa budaya merupakan perkembangan dari kata majemuk budi-daya yang berarti daya dari akal, yaitu berupa cipta, karsa, dan rasa. Dengan demikian kebudayaan diartikan sebagai hasil dari cipta, karsa, dan rasa. Jadi tiap perbuatan manusia baik yang berupa ide, tingkah laku, maupun karya membentuk suatu kebudayaan.

Kata tradisi berasal dari bahasa Latin tradere yang berarti menyerahkan, memberikan, meninggalkan. Tradisi tumbuh dan berkembang dalam kehidupan masyarakat dan terungkap melalui bahasa, perilaku, dan adat istiadatnya. Melalui proses pewarisan dan pendidikan, tradisi diteruskan dari satu generasi ke generasi berikutnya. Tradisi yang telah berlangsung lama disebut dengan tradisi kultural atau budaya tradisi. Tradisi merupakan kumpulan warisan mengenai apa dan bagaimana seni itu berdasarkan pemahaman masyarakatnya (Sumardjo, 2000, hlm. 88).

Dengan merujuk pada pengertian budaya dan tradisi, dapat diartikan bahwa budaya tradisi merupakan keseluruhan unsur kebudayaan yang sampai saat ini masih diteruskan dan diwariskan dari generasi sebelumnya. Budaya tradisi dalam bidang seni, dapat dipahami sebagai seni yang merupakan bagian dari kebudayaan yang terintegrasi dengan unsur-unsur budaya lainnya yang diwariskan oleh generasi sebelumnya dan terus dijalankan dengan tidak banyak mengalami perubahan hingga saat ini. Berdasarkan perkembangannya budaya tradisi di Indonesia dapat dikelompokkan ke dalam dua kategori yaitu budaya tradisi yang berkembang di kalangan istana yang melahirkan budaya tradisi klasik dan budaya tradisi yang berkembang di masyarakat luar istana yang bertahan sampai sekarang dan sering disebut budaya tradisi etnik seperti kerajinan keramik.

Pengertian keramik secara umum adalah tanah liat yang dibakar. Adapun titik matangannya berbeda-beda tergantung jenis tanah liat yang digunakan, yakni: Earthenware 950 - 1100 celcius, Stoneware 1200 - 1300 celcius dan Porselen 1300 - 1400 celcius. (Rhodes, 2000, hlm. 69). Mengenai pengertian istilah keramik Frank dan Janet Hamer (1986, hlm. 
53) menyatakan:

Clay products made permanent by heat (the ceramic change); also the study of this subject. The word comes from the Greek keramos meaning potters clay and the ware made from it but it is used to describe non clay refractories which are changed or formed by heat and also many silicate products. It is often used by the individual potter when the name 'pottery' seems to limiting a description of the work.

Berdasarkan kutipan tersebut dapat diketahui bahwa keramos artinya barang pecah belah atau barang dari tanah yang dibakar, berasal dari bahasa Yunani, dan merupakan asal kata dari keramik. Berkaitan dengan istilah keramik, di Indonesia muncul istilah gerabah yang mengacu pada pada benda atau produk keramik suhu rendah dengan pembakaran dibawah suhu 1.000 celcius. (Yana, 2014, hlm. 353). Sebagai produk budaya, keramik merupakan perwujudan ide, teknologi, nilai maupun norma yang dianut oleh masyarakat pembuatnya. Hal inilah yang menyebabkan setiap daerah memiliki bentuk keramik yang khas dan berbeda dengan daerah lainnya. (Irfan, 2019, hlm. 73).

\section{Keramik Sitiwinangun dan Budaya Tradisi}

Berdasarkan identifikasi dapat diketahui bahwa sentra kerajinan keramik Sitiwinangun telah ada sejak masa penyebaran agama Islam di pulau Jawa. Budaya tradisi pembuatan kerajinan keramik di Sitiwinangun merupakan yang tertua di Jawa Barat dan kemudian menyebar ke daerah lainnya seperti Plered di Kabupaten Purwakarta yang kemudian berkembang menjadi salah satu sentra kerajinan keramik yang sangat terkenal (wawancara Ratija Bratamenggala, 6 Desember 2019). Awalnya keterampilan membuat keramik digunakan sebagai media penyebaran agama Islam danuntuk membekali masyarakatnya agar memiliki keahlian sebagai mata pencaharian sehingga tidak perlu meninggalkan kampung halaman untuk merantau mencari pekerjaan. Seperti pepatah pendiri Desa Sitiwinangun Ki Bagus Pranata yaitu sing kali oli wedi, sing sawah oli lemah, sing tegal oli sungkrah. Artinya dari sungai dapat pasir sebagai campuran untuk bahan keramik, dari sawah mendapat tanah (liat), dari ladang mendapat sampah, daun-daun kering sebagai bahan bakar (Fimahatmadja, 2005, hlm. 37). Bahkan dalam rangka memotivasi dan membangun kompetensi teknis dan estetis perajinnya ada tradisi yang biasa dilakukan oleh masyarakat Desa Sitiwinangun yang ingin belajar membuat keramik hingga saat ini yaitu mengelilingi pagar makam Ki Jaya Baya dengan ritual khusus yang dipercaya akan menentukan jenis dan tingkat kemahiran dalam membuat keramik bagi yang melakukannya, apakah akan memiliki kepandaian membuat barang-barang keramik berukuran besar, seperti: gentong, gosang dan paso, atau hanya akan memiliki kepandaian membuat keramik ukuran kecil seperti kendi, pendil, cobek, dan lain-lain.

Sebagai aktifitas sosial dan mata pencaharian masyarakatnya, kerajinan keramik Sitiwinangun memiliki potensi dan kendala baik dalam aspek material, teknik, bahan bakar, desain, dan pemasarannya. Tanah liat sebagai bahan baku utama untuk 

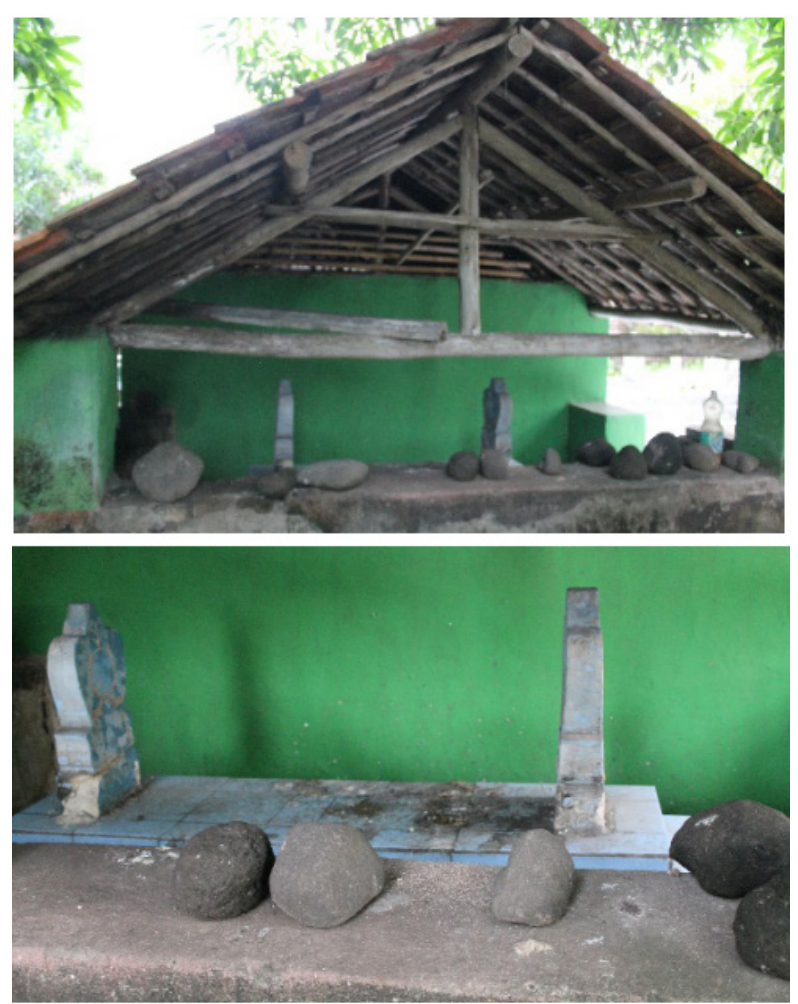

Gambar 1-2. Makam Ki Jaya Baya dan batu untuk ritual di Desa Sitiwinangun

(Sumber: Deni Yana, 2017)

membuat keramik suhu rendah (Earthenware) depositnya masih cukup banyak yang dapat diperoleh oleh perajin Sitiwinangun dari area persawahan di sekitar sentra. Tanah liat tersebut kemudian dicampur pasir halus dari pinggiran sungai agar struktur body-nya lebih kuat dan tidak mudah pecah baik dalam proses pembentukan, pengeringan, maupun pembakaran (Gambar 3-4). Permasalahannya adalah standar kualitas bahan baku yang masih rendah karena proses pengolahannya yang masih tradisional dengan teknologi dan peralatan yang masih sederhana. Dengan demikian tanah liat yang dihasilkannya masih kasar sehingga berpengaruh secara langsung terhadap prosentase kegagalan produksi dan rendahnya kualitas produk yang dihasilkan.
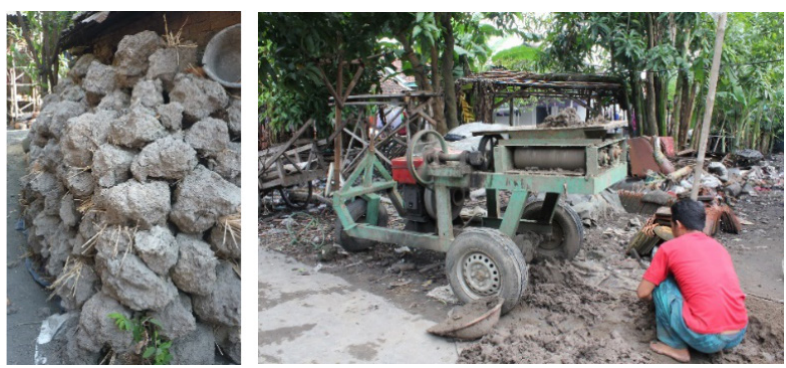

Gambar 3-4. Proses penyiapan bahan baku di sentra kerajinan Keramik Sitiwinangun

(Sumber: Deni Yana, 2018)

Perajin keramik Sitiwinangun umumnya hanya membuat produk keramik bila ada pesanan, sehingga jenis produknya menjadi sangat terbatas dan secara ekonomi kurang menguntungkan. Keramik yang dibuat merupakan pengulangan bentuk yang sudah ada, hal ini mengakibatkan produk keramiknya tidak berkembang baik secara fungsi maupun estetik sehingga kurang sesuai dengan perkembangan dan kebutuhan konsumen saat ini. Dengan demikian, maka sangat perlu adanya rekonstruksi dan transformasi nilai-nilai budaya lokal ke dalam produk baru agar nilai-nilai yang dianggap kontra produktif dapat direkonstruksi sedemikian rupa menjadi kekuatan internal yang dapat mengakomodasi nilai-nilai modernitas tanpa harus mengorbankan nilai-nilai kearifan lokal. (Basyari, 2013, hlm. 115).

\section{Ciri Khas dan Identitas Keramik Sitiwinangun}

Kerajinan keramik sebagai produk budaya yang merupakan perwujudan ide, aktifitas sosial dan karya masyarakat tertentu sudah pasti memiliki kekhasan yang berbeda antara satu daerah dengan daerah lainnya. Di Indonesia, setiap daerah memiliki teknik pembuatan keramik, gaya dan ciri khasnya 
masing-masing. (Sudiyati, 2012, hlm. 10). Ciri khas inilah yang merupakan potensi untuk pengembangan keramik Sitiwinangun saat ini dalam upaya menciptakan produk baru yang lebih modern namun tetap memiliki identitas lokal. Identitas budaya adalah rincian karakteristik atau ciri-ciri sebuah kebudayaan yang dimiliki oleh sekelompok orang yang kita ketahui batas-batasnya tatkala dibandingkan dengan karakteristik atau ciri-ciri kebudayaan orang lain. (Haryati, 2013, hlm. 8).

Hal yang menarik pada sentra kerajinan keramikSitiwinangunyaitumasihbertahannya pembuatan keramik tradisional dengan teknik pembentukan tatap pelandas (paddle anvile) yang telah berkembang di Indonesia sejak masa prasejarah. Selain itu, dikembangkan juga teknik handbuilding dan teknik putar dengan menggunakan alat putaran tangan (handwheel). Kemudian teknik pembakaran yang digunakan masih menggunakan tungku ladang (open firing) secara tradisional yang sangat khas dengan durasi yang sangat cepat yakni hanya sekitar 45 menit dengan bahan bakar jerami, ranting, bambu, dan karet bekas yang sangat atraktif sehingga banyak menarik perhatian pengunjung yang datang ke sentra. Sementara dekorasi produknya banyak menggunakan teknik toreh dan tempel yang masih sederhana namun dibuat dengan keterampilan dan kepekaan estetik yang sangat tinggi (Gambar 5-7). Keterampilan dan artistik yang tinggi merupakan salah satu ciri khas dan kelebihan para perajin di Indonesia termasuk Sitiwinangun. Bangsa Indonesia dianugerahi banyak insan terampil yang punya bakat, kerajinan, ketekunan,
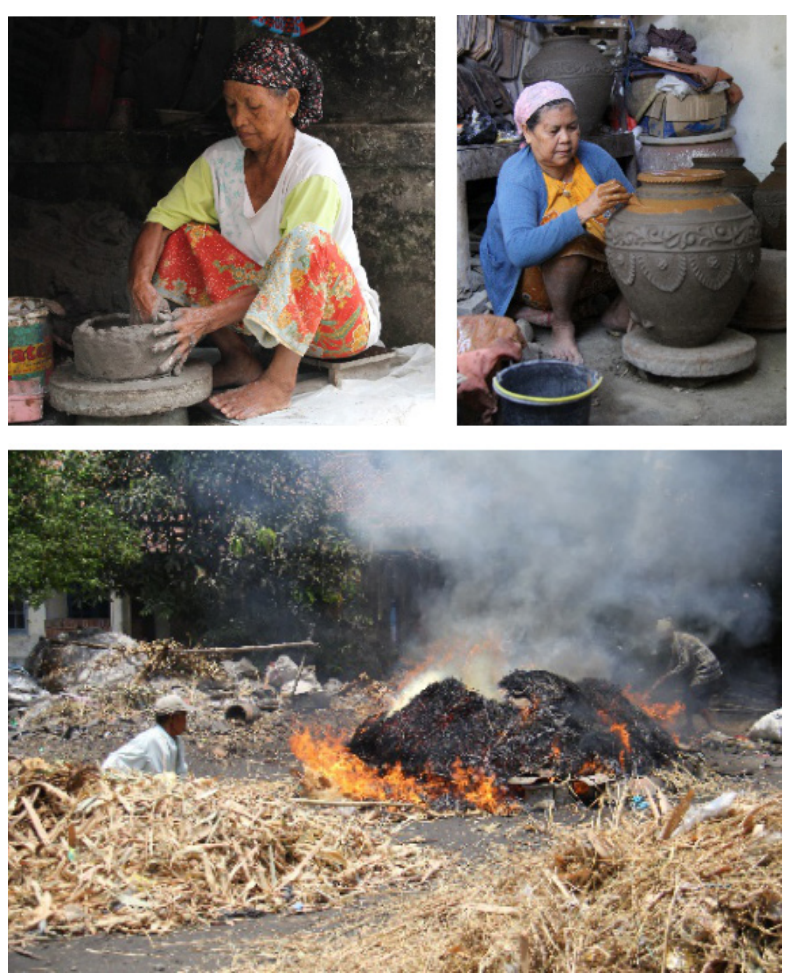

Gambar 5-7. Proses pembentukan, dekorasi dan pembakaran kerajinan keramik Sitiwinangun (Sumber: Deni Yana, 2017)

sensitivitas, sensibilitas, dan citra-rasa tinggi yang dikembangkan dalam berbagai bentuk karya seni. (Wagiono, 2009, hlm. 301). Pewarnaan produk keramik umumnya menggunakan pewarna tanah (Engobe) sehingga karakternya terkesan natural, dof dengan tekstur yang masih kasar. Adapun untuk menghaluskan permukaan produknya pada tahap akhir proses pembentukan dan dekorasi dilakukan penggosokan (burnishing) dengan menggunakan kain, bambu atau batu.

Berdasarkan fungsinya produk kerajinan keramik Sitiwinangun dapat dikelompokan kedalam empat kelompok yakni: keramik pakai/fungsional, keramik ritual keagamaan, keramik simbolis, dan estetis (hias).

Keramik pakai/fungsional adalah keramik yang memiliki nilai guna/pakai untuk kebutuhan sehari-hari. Jenis produknya berupa pendil, paso, kuali, gosang, dan lain- 
lain. Selain keramik yang digunakan sebagai alat dapur, termasuk juga didalam kelompok ini yaitu celengan sebagai tempat untuk menyimpan uang. Jenis keramik ini umumnya berbentuk sederhana, lebih mengutamakan fungsi, tidak menggunakan hiasan atau dekorasi dan teksturnya cenderung kasar dengan finishing yang tidak begitu detail. Namun ada juga beberapa produk keramik pakai yang menggunakan ragam hias mega mendung, sulur, wadasan, dan lain-lain sebagai dekorasinya.

Produk kerajinan keramik Sitiwinangun untuk kepentingan religi dan keagamaan antara lain memolo dan padasan (Gambar 1011). Memolo atau mastaka artinya pucuk atau mahkota berfungsi sebagai penutup ujung atap pada bangunan masjid sebagai tempat peribadatan pemeluk agama Islam (Yana, 2017, hlm. 236). Adapun padasan adalah gentong yang memiliki lubang pada bagian bawahnya yang difungsikan sebagai tempat keluarnya air untuk berwudlu. Kedua jenis produk ini biasanya dibuat dengan bentuk yang memiliki kompleksitas tinggi serta dilengkapi dengan ornamen yang sangat rumit dan dinamis sehingga memerlukan tingkat keterampilan yang sangat tinggi dari pembuatnya. Memolo dan padasan merupakan produk yang menjadi ciri khas sentra kerajinan keramik Sitiwinangun karena tidak ditemukan di sentra keramik lainnya di Indonesia. (Yana, 2019, hlm. 21)

Selain memolo dan padasan ada juga beberapa produk pakai/fungsi yang sering digunakan dalam upacara ritual agama dan tradisi atau kepercayaan yang berkembang
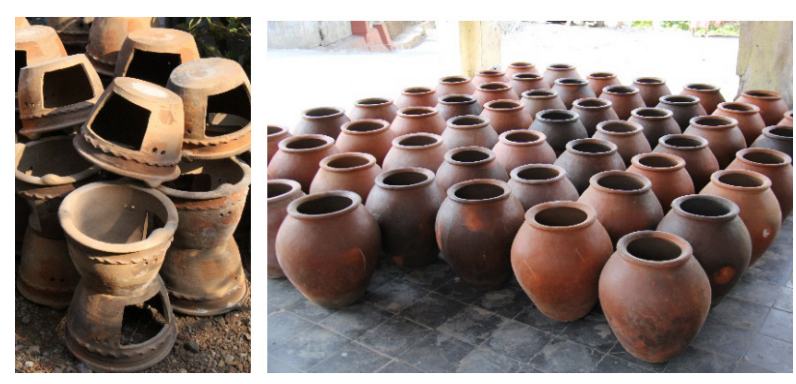

Gambar 8-9. Produk kerajinan keramik Sitiwinangun untuk fungsi pakai.

(Sumber: Deni Yana, 2014)
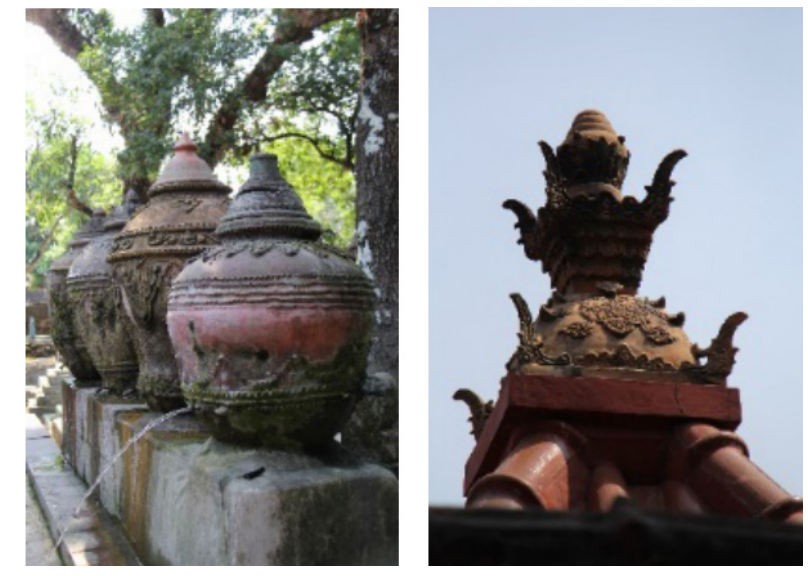

Gambar 10-11. Padasan dan Memolo (Sumber: Deni Yana, 2014)

dalam masyarakat setempat seperti buyung, paso, kepingan keramik, cuwo dan kendi untuk upacara tujuh bulan kehamilan. Selain itu, pendil juga sering digunakan dalam upacara kelahiran sebagai tempat untuk menyimpan ari-ari bayi yang baru lahir. Buyung dan gentong selain fungsi pakai utamanya, juga sering digunakan sebagai wadah untuk menyimpan uang dari tamu undangan dalam upacara khitanan. Sementara dalam upacara pernikahan, selain kendi, hampir semua jenis keramik fungsional digunakan dalam upacara pernikahan selain juga sebagai bagian dari barang seserahan dari pihak mempelai pria. Selain dalam upacara kelahiran dan pernikahan, dalam upacara kematian pun kendi sering digunakan sebagai alat untuk menyiram air disamping padupaan untuk 
menyalakan dupa.

Selain produk keramik fungsi dan religi, ada juga beberapa patung keramik tradisional yang ditemukan di sentra kerajinan keramik Sitiwinangun dalam wujud Paksinagaliman, Macan Ali, Singabarong, Burok, Jatayu, Garuda Mungkur dan Gajah Mungkur yang apabila dilihat dari segi bentuk, gaya dan teknik secara umum dapat dikategorikan bergaya klasik dengan bentuk sebagai perwujudan dari ular Naga, burung Garuda, Gajah dan Macan (Gambar 12-14) dalam ukuran yang cukup besar (panjang dan lebar diatas $50 \mathrm{~cm}$, berat lebih dari $10 \mathrm{~kg}$ ). Patung-patung keramik ini merupakan budaya tradisi khas Sitiwinangun yang juga tidak ditemukan pada sentra kerajinan keramik lainnya di Indonesia. Pada awalnya patung keramik tersebut dibuat untuk tujuan simbolik sebagai pernyataan kekuatan dan penyatuan unsur-unsur kekuasaan dalam bentuk perupaan (Laili, 2007, hlm. 46).

Dari sekian banyak patung simbolik tersebut, Paksinagaliman merupakan patung yang paling terkenal dan sangat identik dengan budaya Cirebon sebagai hasil akulturasi budaya Nusantara, India, dan Cina. Dalam bahasa Sansekerta Paksi berarti burung (Garuda) yang merupakan simbol dari kekuatan di udara dan budaya Nusantara, Naga merupakan simbol kekuatan di lautan dan budaya Cina, serta Liman berarti Gajah merupakan simbol kekuatan di daratan dan budaya India. Selain itu sebagai akulturasi dengan budaya Timur Tengah (Islam) muncul patung Burok sebagai perwujudan dari mahluk yang digunakan sebagai kendaraan Nabi Muhammad SAW dalam peristiwa Isra Mi'raj
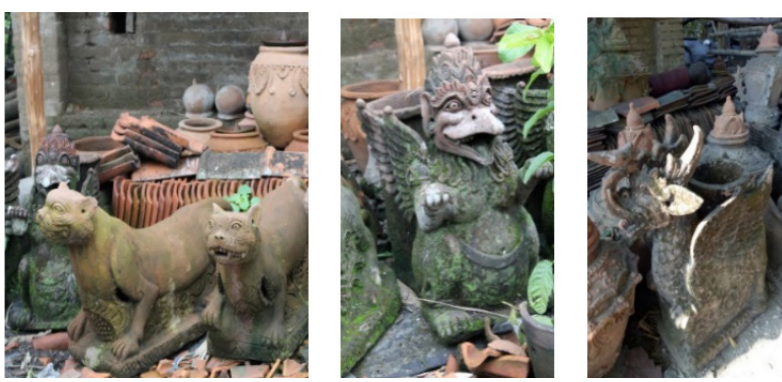

Gambar 12-14. Beberapa produk patung mitos keramik Sitiwinangun. (Sumber: Deni Yana, 2019)

dan patung Macan Ali sebagai perlambangan kekuatan masyarakatCirebon yang terinspirasi dari keperkasaan dan kepahlawanan Sayidina Ali serta kalimat tauhid dalam Islam yang tertulis dan membentuk macan dalam bendera kesultanan Cirebon.

Produk kerajinan keramik Sitiwinangun selain ada yang berfungsi sebagai benda pakai, religi, dan simbolis, ada juga yang dibuat oleh perajinnya hanya untuk tujuan keindahan atau hias/dekoratif. Produknya berupa vas, jambangan, topeng, hiasan dinding dan atap, dan lain-lain yang secara visual lebih menarik perhatian melalui aplikasi bentuk dan motif khas keramik Sitiwinangun.

Selain momolo, padasan, dan patung mitos, ciri khas lain yang dimiliki oleh keramik Sitiwinangun yaitu motif atau ragam hias. Megamendung merupakan motif/ragam hias yang sangat terkenal dan telah menjadi salah satu ikon budaya Cirebon. Motif/ragam hias ini merupakan hasil akulturasi budaya Cirebon dengan Cina yang melambangkan dunia atas dan kesuburan. Selain Megamendung di Cirebon juga berkembang motif Wadasan (berasal dari kata Wadas yang artinya batu karang) sebagai perlambangan dunia bawah dan keteguhan masyarakat Cirebon 
dalam menjalankan syariat agamanya. Bagi masyarakat Cirebon yang mayoritas beragama Islam, motif Wadasan merupakan perlambangan agar dalam kehidupan setiap manusia memiliki dasar yang kokoh sekokoh batu karang, yaitu iman dan akidah agama, yang tidak boleh goyah dan senantiasa istikamah dalam menghadapi godaan dari luar (Faizkasmy, 2016).

Secara bentuk, motif Megamendung dan Wadasan hampir memiliki kesamaan. Perbedaanya adalah Megamendung arah motifnya horizontal menyamping menyerupai awan, sementara Wadasan arah motifnya vertikal dan meruncing menyerupai batu cadas. Motif Megamendung dan Wadasan banyak diaplikasikan pada dinding gerbang keraton, produk batik, ukiran kayu, dan lainlain termasukjuga pada keramikSitiwinangun. Selain kedua motif tersebut, produk kerajinan keramik Sitiwinangun juga memiliki motif/ ragam hiasyang merupakan kekhasan lokalnya yaitu Tepen, Rumbing, Lingkaran Memusat, Melaten, Kembang Kangkung, Sulur Kangkung, Kembang Waluh, Berundakan, Kawung, Bulan Sabit, Tumpal, Linjoan, Untu Walang, Terate, Kaligrafi, Lung Pakis, Oncoman, Kembang Kluih/ Sukun, Kembang Nangka Welandaan, Semanggen, Kembang Tanjung, Gringsingan, Sulur Gelung, Menyan Kobaran dan Simbar (Laili, 2007, hlm. 48).

Berdasarkan pembahasan tersebut, selain teknik pembakaran tungku ladang (open firing), memolo, padasan, patung mitos, dan motif Megamendung merupakan ciri khas utama sekaligus identitas keramik Sitiwinangun yang berbeda dengan keramik
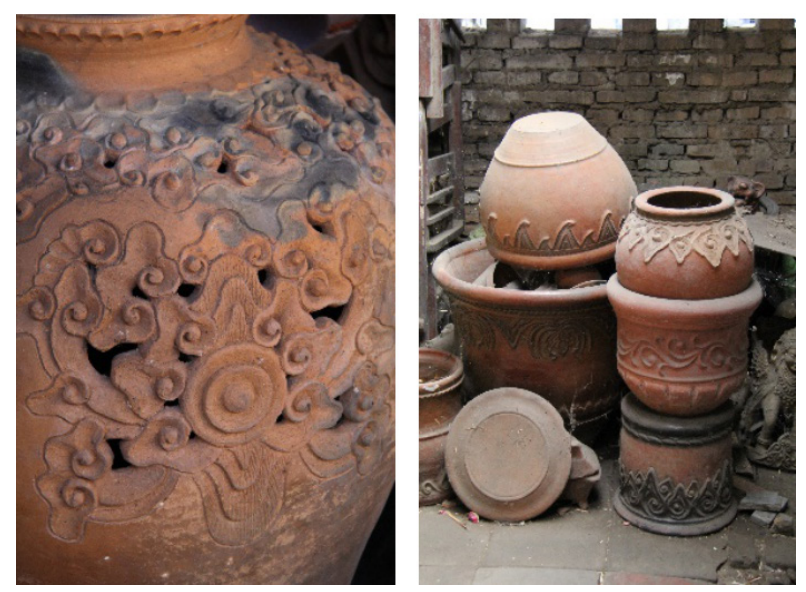

Gambar 15-16. Motif/ragam Megamendung dan Wadasan pada kerajinan keramik Sitiwinangun (Sumber: Deni Yana, 2014)

dari sentra-sentra lainnya di Indonesia.

\section{Identitas dan Basis Pengembangan Kerajinan}

\section{Keramik Sitiwinangun}

\section{A. Konsep Dasar Pengembangan}

Dalam rangka konservasi dan revitalisasi seni tradisi, berdasarkan budaya tradisi dan kekhasan lokalnya baik dalam aspek historis, material, bentuk, dan motif/ragam hias, pengembangkan produk kerajinan keramik Sitiwinangun dilakukan. Upaya yang dilakukan mengacu pada metode Artefack, Technique, Utility, Material, Icon, Concept, Shape (ATUMICS) yang digunakan untuk melakukan transformasi artefak tradisi menjadi produk modern melaui penyusunan, kombinasi, integrasi, atau penggabungan antara elemen objek yakni: artefak, teknik, utility, material, ikon, konsep, dan bentuk.

Tahapan awal yang dilakukan dalam proses pengembangan yaitu menentukan seleksi terhadap beberapa budaya tradisi yang menjadi ciri khas keramik Sitiwinangun baik proses produksi, bentuk, dan motif untuk dijadikan dasar pengembangan dalam rangka 
menghasilkan produk baru yang lebih modern namun tetap dapat menonjolkan ciri khas sebagai identitas dari keramik Sitiwinangun. Berdasarkan hal tersebut, disamping teknik pembakaran tungku ladang (open firing), bentuk patung mitos (Paksinagaliman) dan ragam hias (Megamendung) menjadi pilihan utama dalam proses pengembangan penelitian Berdasarkan temuan di lapangan, di sentra keramik Sitiwinangun terdapat tujuh bentuk patung mitos yaitu Paksinagaliman, Singabarong, Macan Ali, Burok, Jatayu, Garuda Mungkur, dan Gajah Mungkur, yang sangat terkenal dan sudah menjadi ikon budaya Cirebon. Patung binatang mitologi Paksinagaliman merupakan hasil olahan bentuk yang berasal dari kereta kerajaan Cirebon. Patung-patung mitos tersebut yang pada masa lalu berfungsi sebagai simbol dari kosmologi masyarakat Cirebon sekarang sudah mengalami pergeseran hanya sebagi benda hias, dengan kualitas teknis dan estetis yang perlu ditingkatkan kualitasnya agar dapat menarik minat pengunjung atau konsumen.

Walaupun keramik Sitiwingun memiliki 25 jenis motif/ragam hias lainnya, dapat dikatakan bahwa keramik Sitiwinangun tanpa motif Megamendung dan Wadasan akan sulit dibedakan dengan produk keramik dari sentra lain yang memiliki kemiripan dalam aspek material, teknik, bentuk, dan dekorasi. Dengan demikian, dapat dikatakan bahwa motif/ragam hias Megamendung dan Wadasan merupakan salah satu ciri khas dan identitas kerajinan keramik Sitiwinangun. Umumnya motif/ragam hias Megamendung dan Wadasan

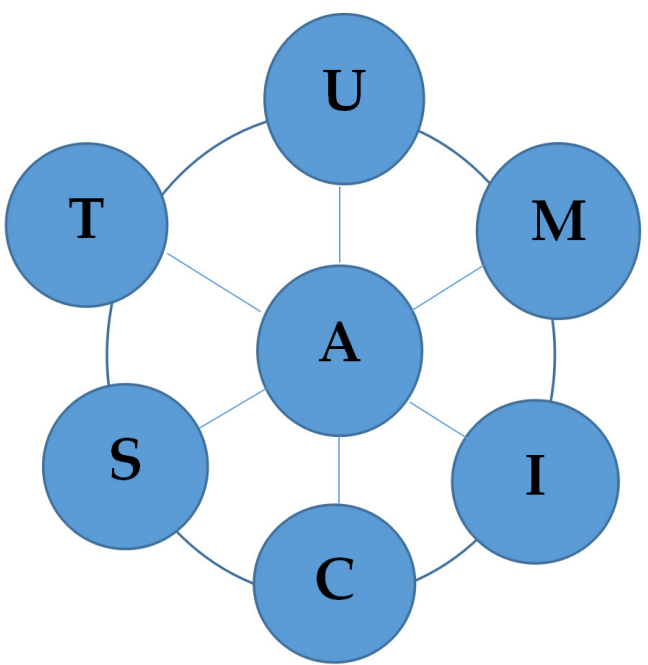

Bagan 1. Elemen artefak/objek dalam metode ATUMICS Sumber: "Transforming Tradition: A Method for Maintaining Tradition in a Craft and Design Contex" (Adhi Nugraha, 2012, hlm. 177)

digunakan hanya untuk menghias permukaan benda keramik seperti gentong, jambangan, vas, pot bunga, dan lain-lain sehingga eksistensinya kurang menonjol. Hal ini akan sangat berbeda bila motif/ragam hias tersebut beserta bentuk dasarnya dieksplorasi secara optimal ke dalam produk baru yang lebih modern.

\section{B. Proses Desain dan Aplikasinya}

Proses pengembangan desain dalam penelitian ini dilakukan secara partisipatif dengan melibatkan para perajin keramik Sitiwinangun dengan mengacu pada metode ATUMICS dan konsep pembuatan keramik secara umum. Maka dari itu, dibuat tiga kategori atau kelompok produk pengembangan yaitu karya seni, benda hias, dan benda pakai (fungsional).

Pada sentra kerajinan keramik Sitiwinangun, patung-patung mitos yang pada masa lalu berfungsi sebagai simbol dari kosmologi masyarakat Cirebon, sekarang 

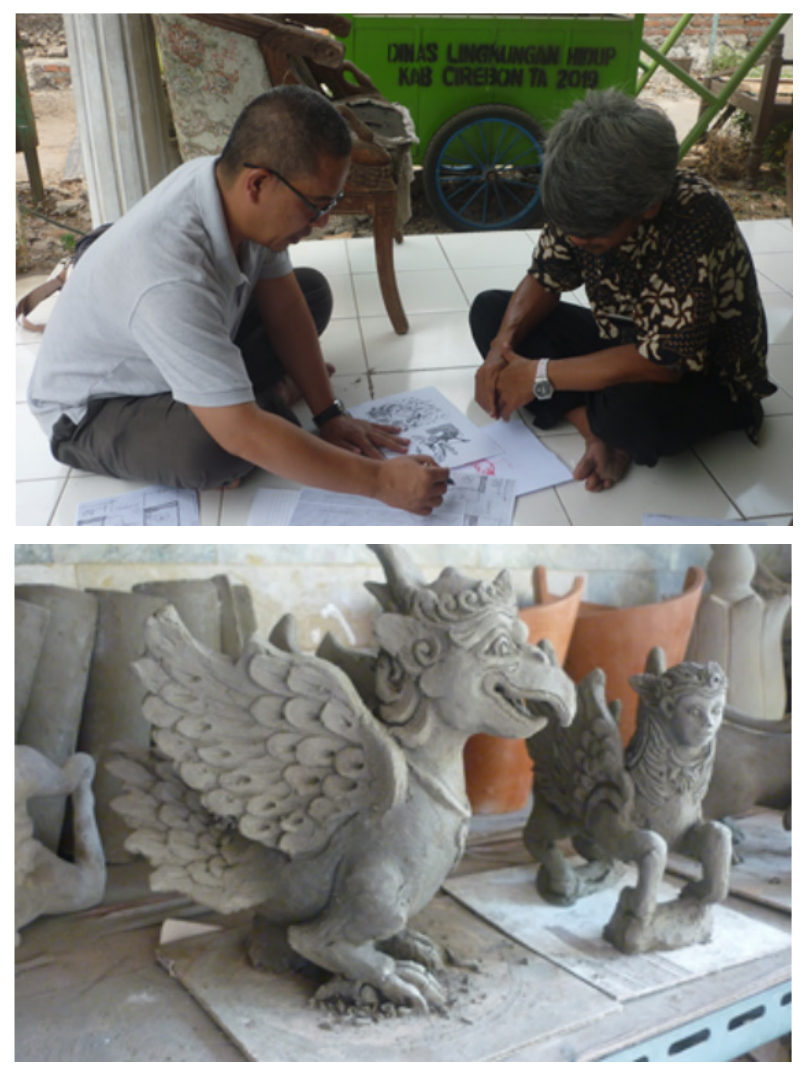

Gambar 17-18. Proses sketsa/desain dan aplikasi di sentra kerajinan keramik Sitiwinangun (Sumber : Deni Yana, 2019)

sudah mengalami pergeseran hanya sebagai benda hias biasa dan banyak ditemukan dengan standar teknis dan estetis yang perlu ditingkatkan kualitasnya. Umumnya patung-patung yang ditemukan di sentra berukuran besar, bobotnya cukup berat, dan finishing-nya masih kasar dengan image yang cenderung mistis sehingga dalam penelitian ini dilakukan pengembangan dengan cara melakukan perubahan terhadap konsep, bentuk, dan fungsinya walaupun masih tetap menggunakan teknik, material dan ikon lama.

Dengan ukuran yang lebih kecil, tipis, dan ringan, menjadikan produk atau karya keramik Sitiwinangun hasil pengembangan ini lebih sesuai dengan kebutuhan konsumen saat ini yang umumnya tinggal dengan ruang yang lebih terbatas. (Sriwardani, 2014,
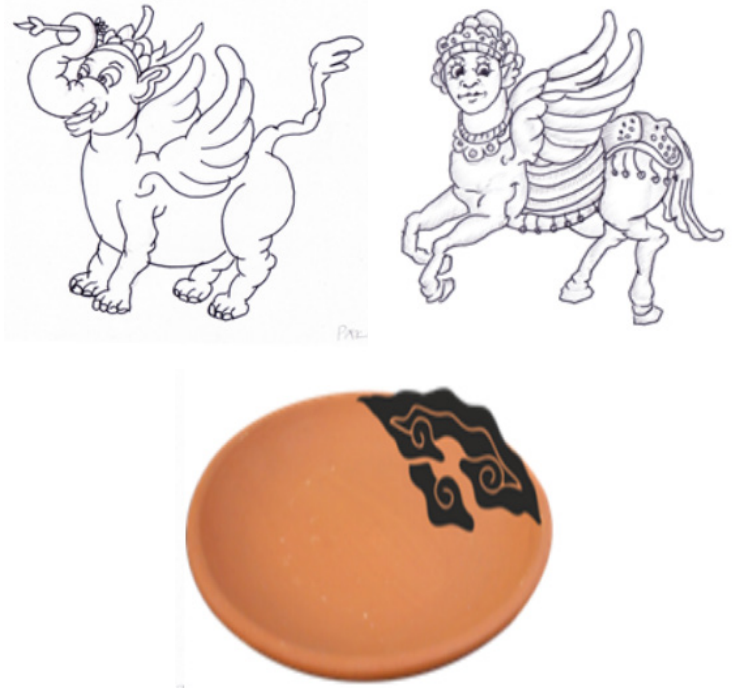

Gambar 19-21. Contoh desain/sketsa pengembangan patung mitos dan motif Megamendung.

(Sumber: Deni Yana, Gustiyan Rachmadi, M. Ikhsan, 2019)

hlm. 69). Walaupun dibuat dengan teknik pembentukan, dekorasi, dan pembakaran yang masih menggunakan cara lama (tradisional), ketika bentuk dan anatominya dibuat lebih humanis dan proses finishing-nya dimaksimalkan menjadi lebih halus dengan pewarna tanah (Engobe) lokal yang diolah secara optimal maka dapat dihasilkan produk atau karya seni yang memiliki kualitas teknis dan estetis yang tinggi.

Selain menjadi karya seni, patung mitos ini juga dikembangkan menjadi produk hias berupa suvenir atau cendera mata karena ukurannya yang kecil dan bentuknya yang unik. Beberapa dari produk tersebut juga dieksplorasi bentuk dan fungsinya sehingga selain benda hias juga dapat digunakankan sebagai benda fungsi seperti tempat pensil, asbak, vas, dan lain-lain.

Hasil dari proses ini walaupun dengan material tanah liat yang sama tetapi dengan teknik pewarnaan menggunakan cat, dapat dihasilkan produk-produk dengan tema yang 

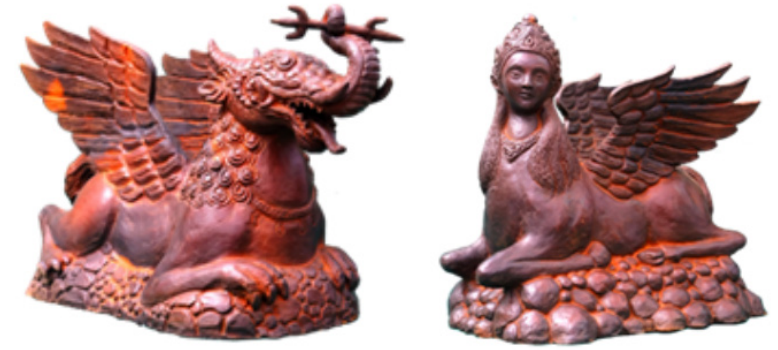

Gambar 22-23. Patung mitos Paksinagaliman dan Burok hasil pengembangan (karya seni).

(Sumber: Deni Yana dan Gustiyan Rachmadi, 2019)
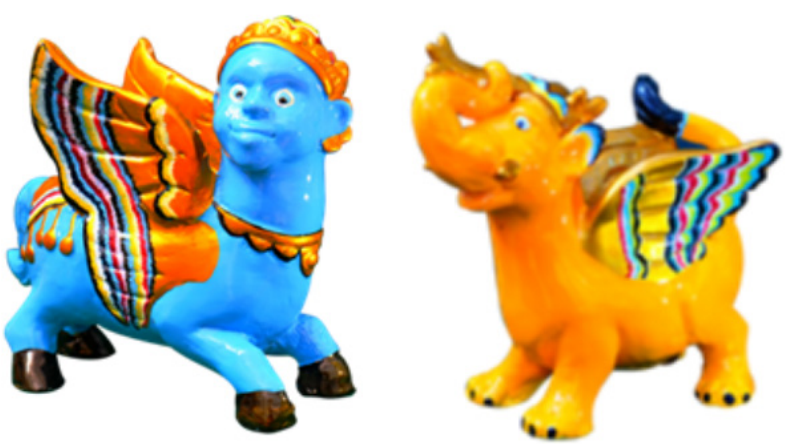

Gambar 24-25. Patung mitos Paksinagaliman dan Burok hasil pengembangan (keramik hias/souvenir). (Sumber: Deni Yana dan Gustiyan Rachmadi, 2019)

sama tapi dengan tampilan bentuk, warna, dan karakter yang sangat berbeda. Secara bentuk lebih terkesan lucu, naif, dan menyenangkan. Adapun warna cat yang digunakan telah disesuaikan dengan trend forecasting 2019/2020 dengan tema Exuberant yang identik dengan bentuk yang jenaka dan warna-warna cerah yang dapat meningkatkan energi. Hal ini sangat berbeda dengan karakter warna dan finishing patung mitos Sitiwinangun sebelumnya yang masih natural dengan warna terakotanya. Jenis dan karakter warna yang paling disukai konsumen kerajinan keramik lokal di Indonesia pada umumnya berwana cerah dengan permukaan yang mengilap. (Yana, 2014, hlm. 31).

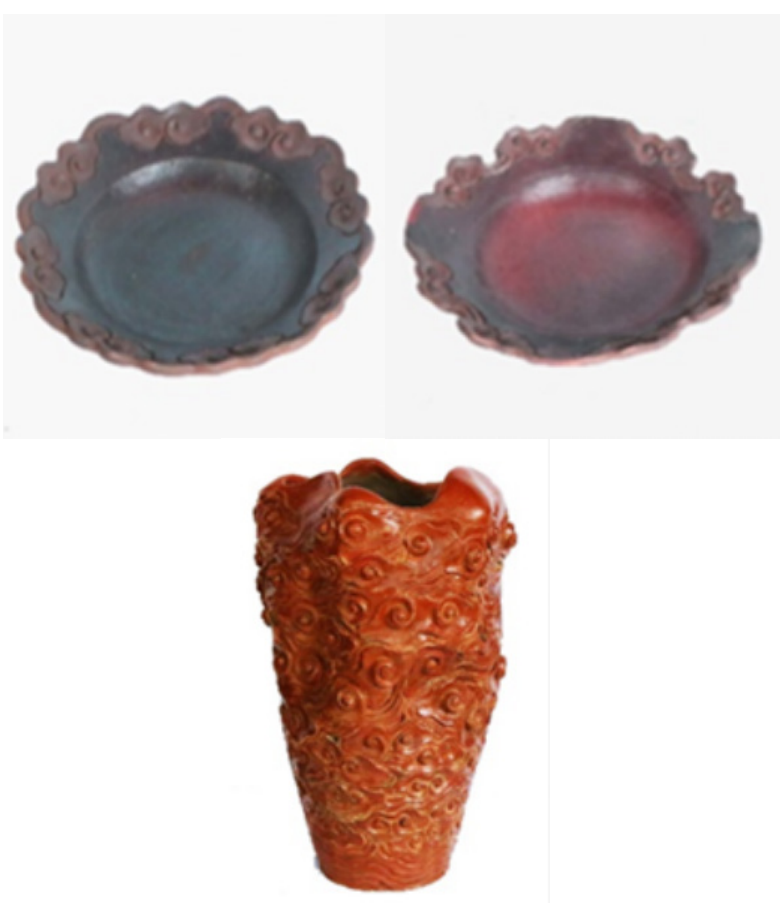

\section{Gambar 26-28. Keramik Sitiwinangun hasil pengembangan berbasis motif Megamendung (Sumber: Deni Yana, Akbar Adhi Satrio, M. Ikhsan, 2019)}

Pengembangan berikutnya yaitu pemanfaatan motif hias Megamendung untuk menghasilkan keramik berupa karya seni dalam bentuk vas dan benda fungsi/pakai tableware dalam bentuk piring. Motif/ragam hias Megamendung beserta bentuk dasarnya dieksplorasi secara optimal menjadi kesatuan bentuk karya yang sangat unik dengan garis yang sangat dinamis dan estetis. Hasil eksplorasi tersebut menghasilkan produk keramik baru yang modern dengan konsep dan fungsi baru, dari produk fungsional untuk benda pakai menjadi karya seni untuk fungsi ekspresi dengan ikon, material, dan teknik (pembentukan, dekorasi, dan pembakaran) yang masih tradisional.

Motif Megamendung juga digunakan pada produk keramik fungsional/pakai yang dikembangkan dalam bentuk tableware berupa piring. Material yang digunakan adalah 
tanah liat Sitiwinangun dengan pewarna tanah (Engobe) lokal dan pembakaran tungku ladang (open firing). Teknik pembentukannya menggunakan teknik putaran tangan (perbot). Pewarnaannya menggunakan Engobe natural Sitiwinangun. Proses finishingnya lebih dimaksimalkan dengan menggunakan teknik gosok (burnis) sehingga permukaan piringnya setelah dibakar menjadi halus, licin, dan lebih mengilap. Warna body yang dihasikan merah kehitaman, gelap, dan natural sebagai efek reduksi dalam proses pembakarannya. Perangkat tableware yang sudah dibuat sebelumnya di sentra kerajinan keramik Sitiwinangun baru sebatas teko dan cangkir dalam jumlah yang sangat terbatas. Kebanyakan produk keramik fungsional/ pakai yang dibuat sebelumnya berupa, gentong, pasu, tempayan, dan lain-lain sehingga dikembangkan produk tableware berupa piring untuk memenuhi kebutuhan konsumen saat ini dengan menjamurnya bisnis hotel dan restauran. Jadi dalam pembuatan keramik fungsional/pakai ini yang diubah adalah bentuk, fungsi, dan kosep produknya, sementara aspek teknis, material, dan ikonnya tetap (tradisional). Hal yang menarik adalah walaupun dengan teknik dan material yang masih tradisional, bila dibuat dengan desain yang baik, proses pembentukan dan dekorasi serta finshing yang maksimal, dapat dihasilkan produk baru yang lebih modern tetapi tetap memiliki identitas lokal yang kuat dan sangat berbeda dengan produk yang sudah ada sebelumnya.

\section{PENUTUP}

Dari sekian banyak potensi dan kekhasan lokalnya, teknik pembakaran tungku ladang (open firing), bentuk patung mitos seperti Paksinagaliman dan motif/ragam hias Megamendung serta Wadasan merupakan budaya tradisi lokal yang dapat digunakan sebagai basis pengembangan produk kerajinan keramik Sitiwinangun dalam upaya konservasi dan revitalisasi sentra.

Melalui kajian dan analisis terhadap artefak, teknik, fungsi, material, ikon, konsep, dan bentuk kerajinan keramik tradisional Sitiwinangun dan penggunaan budaya tradisi lokal berupa patung mitos dan motif/ragam hias melaui metode ATUMICS dilakukan proses pengembangan produk melaui tahapan identifikasi, analisis, pengembangan desain, aplikasi desain, dan evaluasi. Hasil dari proses pengembangan tersebut yaitu produk keramik baru yang lebih modern berupa karya seni, hias, dan fungsi yang berbeda dengan produk kerajinan keramik Sitiwinangun yang telah ada sebelumnya dalam aspek fungsi, konsep, dan bentuknya.

Budaya tradisi lokal yang digunakan dalam penelitian ini digunakan untuk kepentingan pengembangan dan inovasi. Budaya tradisi tersebut ditampilkan oleh peneliti lewat produk dan karya keramik yang lebih humanis dan bersifat karikatural dalam bentuk figur keramik seperti Paksinagaliman dan Burok serta benda fungsi berupa piring dengan motif/ragam hias Megamendung dan Wadasan. 
Penelitian mengenai pengembangan kerajinan keramik Sitiwinangun berbasis budaya tradisi lokal ini akan memiliki kontribusi yang cukup besar terhadap perkembangan keramik tradisional dan modern di Indonesia secara umum karena dapat membuktikan bahwa keramik tradisional dapat dikembangkan menjadi produk baru dengan memanfaatkan ciri khas dan identitasnya sebagi kekuatan dalam upaya menghasilkan produk baru yang lebih modern serta memiliki kualitas yang tinggi baik secara teknis maupun estetis sesuai dengan perkembangan zaman.

\section{Ucapan terima kasih}

Penulis mengucapkan terima kasih yang sebesar-besarnya kepada 1) Dr. Wanda Listiani, S.Sos., M.Ds., selaku Ketua LPPM ISBI Bandung atas kepercayaanya kepada penulis untuk menjadi ketua pelaksana kegiatan penelitian berbasis karya seni yang didanai dari DIPA ISBI Bandung tahun 2019; 2) Ir. E. Ratna Utarianingrum, M.Si , selaku Direktur IKM Kimia, Sandang, Kerajinan dan Industri Aneka Direktorat Jenderal IKM dan Aneka Kementerian Perindustrian Republik Indonesia yang telah memberi kepercayaan kepada penulis sebagai Ketua Tim Tenaga Ahli kegiatan Pendampingan Teknis Produksi dan Desain IKM Keramik Sitiwinangun di Kabupaten Cirebon Tahun 2018; 3) Dr. M. Ikhsan, M.Ds. dan Akbar Adhi Satrio, M.Ds., selaku anggota tim Pendampingan Teknis Produksi dan Desain IKM Keramik Sitiwinangun di Kabupaten Cirebon Tahun 2018; 4) Dr. Gustiyan Rachmadi, M.Sn., selaku anggota tim pelaksana Penelitian Berbasis Karya Seni ISBI Bandung tahun 2019; 5) Prof. Dr. Reiza D. Dienaputra, M.Hum., selaku Ketua Tim Promotor dan Dr. Agus S. Suryadimulya dan Dr. Yan Yan Sunarya, M.Ds. selaku Co Promotor pada studi program doktor di Fakultas Ilmu Budaya (FIB) Universitas Padjadjaran yang telah memberikan banyak saran, masukan dan kritikan serta motivasi kepada penulis; semoga Allah SWT membalas kebaikan Bapak dan Ibu semuanya.

\section{Daftar Pustaka}

Basyari, Iin W. (2013). Menanamkan Identitas Kebangsaan Melalui Pendidikan Berbasis Nilai-Nilai Budaya Lokal. Edunomic., 1 (2), 112-118.

Bratamenggala, Ratija. 2016. Rencana Pembangunan Jangka Menengah (RPJM) Desa Sitiwinangun Kecamatan Jamblang Kabupaten Cirebon Tahun 2016-2021. Cirebon: Desa Sitiwinangun. Chamidah, Nurul. (2019). Peranan Pentahelix Pemangku Kepentingan Pariwisata dalam Pengembangan Desa Wisata di Kabupaten Cirebon. Disertasi Doktor Universitas Gajah Mada, Yogyakarta.

Dinartisti, Paulina. (2013). Mati Surinya Gerabah Sitiwinangun. Dalam I.P. Sidhi,

I.W. Burhan, R. Kustiasih, Saptono, Hariadi (Ed.), Warisan Budaya Wangsa DerbonDermayu. Jakarta: Bentara Budaya.

Direktorat Jenderal Industri Kecil dan Menengah. 2014. Profil Investasi IKM Gerabah dan Keramik Hias Industri Kecil yang Mampu Bertahan dalam Krisis Ekonomi Global. Jakarta: Kementerian Perindusrtian.

Faizkasmy. 2016. Batik Keraton Cirebon \#1Wadasan. Retrivied Desember 1, 2019, from https ://kepulauanbatik.com

Frank dan Hamer, Janet. 1986. The Potter's Dictionary of Materials and Techniques. New York: A \& C Black.

Haryati. (2013). Televisi Lokal dalam Representasi Identitas Budaya. Observasi, 11 (1), 1-22.

Irfan, Darsono, SP. Gustami, Guntur. (2019). Keramik Takalar 1981-2010: Ragam Bentuk dan Perubahan. Panggung, 29 (1), 72-87.

Laili, Khomisatul. (2007). Pengaruh Terapan Islam terhadap Gerabah Tradisional 
Desa Sitiwinangun Cirebon. Skripsi, Yana, Deni. (2014). Potensi Kerajinan Keramik ITB: Bandung.

Maran, Rafael Raga. (2000). Manusia \&

Kebudayaan Dalam Persfektif Ilmu Budaya Dasar.

Jakarta: Rineka Cipta.

Munro, Thomas. (1970). Form and Style In

The Arts: An Introduction To Aesthetic

Morphology,

Ohio: Press of Case Western Reserve University.

Nugraha, Adhi. (2012). Transforming

Tradition A Methode for Maintaining Tradition in a Craft

and Design Contex. Finlandia: Alto University.

Rhodes, Daniel. (2000). Clay and Glazes for

The Potter. Iola : Krause Publications.

Riyanto, Hendrawan. (2000). Seni Terakota Indonesia Kini. Dalam Sugondo, S., S.C.

Wibisono, Heriyanti O. Untoro, Wiwin Djuwita Ramelan, Wiyoso Yudoseputo, E.S. Hardiati (Ed.), 3000 Tahun Terakota Indonesia, Jejak Tanah dan Api. Jakarta: Museum Nasional Indonesia.

Sriwardani, Nani, dkk. (2014). Standardisasi Desain Bentuk dan Ukuran Keramik Hias Plered untuk Elemen Interior. Prosiding Seminar Nasional Nilai dan Makna Seni : Tradisional, Industri Kreatif dan Budaya Urban di Era Globalisasi, Bandung : 19 - 20 Maret 2015. Hal. $69-74$.

Sudiati, N. (2012). Keramik Singkawang Kalimantan Barat, Kajian aspek Estetika.

Disertasi Doktor Universitas Gajah Mada, Yogyakarta.

Sukria Fimahatmadja. (2005). Proses Perwujudan Karya Seni Rupa dalam Membangun Relasi

Antar Individu dengan Kasus Karya Gerabah Tradisi di Beberapa Daerah di Pulau Jawa. Disertasi Doktor ITB, Bandung.

Sumardjo, Jakob. 2000. Filsafat Seni. Bandung: ITB.

Wagiono. (2009). Tinjauan Kritis Peran Pendidikan Tinggi Seni Dalam Pengembangan Industri Kreatif di Indonesia. Panggung, 20 (3), 295-304. 